\title{
Maternal outcome of primigravida patient with term pregnancy with engaged versus unengaged foetal head at onset of labour
}

\author{
Aditi Goyal, Rekha Wadhwani*
}

Department of Obstetrics and Gynecology, Gandhi Medical College, Bhopal, Madhya Pradesh, India

Received: 04 June 2019

Accepted: 01 July 2019

\section{*Correspondence:}

Dr. Rekha Wadhwani,

E-mail:drrekhaw@yahoo.co.in

Copyright: (c) the author(s), publisher and licensee Medip Academy. This is an open-access article distributed under the terms of the Creative Commons Attribution Non-Commercial License, which permits unrestricted non-commercial use, distribution, and reproduction in any medium, provided the original work is properly cited.

\begin{abstract}
Background: The primigravida are a group at risk as their capacity of child bearing has never put to the test, "primigravida is a dark and untired horse". The potential for future child bearing is determined by outcome of first labour. Hence, if first pregnancy results in normal healthy child, patient is mentally better prepared for subsequent pregnancies. Foetal head is said to be engaged when its biparietal diameter, the greatest diameter in an occiput presentation, passes through the pelvic inlet. Unengagement of head in primigravida has long been considered a possible sign of cephalopelvic disproportion.

Methods: The study had 220 primigravida of which 110 had unengaged head as study group and 110 engaged head as controls. Data collection was done and the course of labour in all the patients recorded on partograph and all the patients were studied in detail. Engagement of the head was defined on the basis of Second Pawlik's grip and Crichton's fifth's formula.

Results: Our study shows that higher age group had more number of cases with unengaged head. The patient with engaged head had higher number of vaginal delivery than study group with unengaged head. More number of LSCS i.e. about $39.1 \%$ in study group as compared to $21 \%$ of controls is statistically significant difference ( $p$ value 0.05 ).

Conclusions: We can conclude that primigravida with unengaged foetal head at onset of labour may deliver vaginally with minimal maternal morbidity, if proper monitoring and maintenance of partogram is done.
\end{abstract}

Keywords: Engaged, Foetal head, Labour, Primigravida, Term pregnancy, Unengaged

\section{INTRODUCTION}

The primigravida are a group at risk as their capacity of child bearing has never put to the test, "primigravida is a dark and untired horse". The potential for future child bearing is determined by outcome of first labour. Hence, if first pregnancy results in normal healthy child, patient is mentally better prepared for subsequent pregnancies. The labour that is undualy prolonged can be given one or more of three types of distress namely: foetal, maternal or "obstetrician's distress". 1 The traditional concept, that engagement of head occurs by 38 weeks in primigravida, is not validated in clinical practice. In majority of primigravidas, the engagement occurs between $38-42$ weeks or even during the first stage of labour. ${ }^{2}$

Foetal head is said to be engaged when its biparietal diameter, the greatest diameter in an occiput presentation, passes through the pelvic inlet. Unengagement of head in primigravida has long been considered a possible sign of cephalopelvic disproportion. $^{2-4}$ It is associated with a higher risk of obstructed labour and dystocia. ${ }^{5-6}$ Non engagement at the onset of active phase of labour is a predictor of the risk of caesarean section. The present study was undertaken to determine the maternal outcome of labour in nulliparous women with unengaged head and 
engaged head at term at onset of labour as a case control study. In this study, it has been shown that with careful monitoring of progress of labour and judicial and timely medical intervention it became very much possible to avoid otherwise unnecessary caesarean sections in most of the primigravida with high heads.

\section{METHODS}

This study was Cross-sectional Observational study conducted in the Department of Obstetrics and Gynecology, Gandhi Medical College and associated Sultania Zanana Hospital, Bhopal over a period of one year from March 2017 to February 2018. A total 220 cases were selected.

\section{Inclusion criteria}

- $\quad$ Primigravida with term pregnancy

- Singleton, live foetus with vertex presentation

- No obvious cephalopelvic disproportion.

\section{Exclusion criteria}

- Intrauterine growth retardation

- Previous uterine surgery

- Placenta previa

- Multiple gestation

- Any skeletal deformity

- Foetal distress

- Intrauterine foetal death

- Primigravida with medical complications like diabetes mellitus and hypertension etc. or any other obstetrical complications.
The study had 220 primigravida of which 110 had unengaged head as study group and 110 engaged head as controls. Data collection was done and patients were selected according to inclusion and exclusion criteria, those with unengaged foetal head were placed in group A (study) and those with engaged foetal placed in group B (control). Detailed history specially, regarding the parity, gestational age and duration of pregnancy was recorded in the pre-decided questionnaire. General, systemic and Obstetric examination was done for fundal height, lie, presentation, and engagement, amount of liquor, estimated foetal weight, palpable uterine contractions and foetal heart rate. The course of labour in all the patients recorded on partograph and all the patients were studied in detail. Engagement of the head was defined on the basis of Second Pawlik's grip and Crichton's fifth's formula.

\section{Statistical analysis}

All the data analysis was done using IBM SPSS version20 software. Frequency distribution and cross tabulation was used to prepare the tables .Microsoft office 2010 was used to prepare graphs. Quantitative data was expressed as mean \pm SD whereas categorical data was expressed as percentage, independent $t$ test was used to compare the mean whereas chi square test was used to compare the categorical data. Level of significance was assessed at $5 \%$.

\section{RESULTS}

Mean age of study group $(24.40 \pm 4.06)$ was higher than control $(23.39 \pm 3.66)$, this is statistically significant.

Table 1: Age distribution in study and control group.

\begin{tabular}{|llll|}
\hline Age (years) & Study $n(\%)$ & Controls $n(\%)$ & Total $n(\%)$ \\
\hline$\leq 20$ & $24(21.8)$ & $32(29.1)$ & $6(25.4)$ \\
\hline $21-25$ & $52(47.3)$ & $56(50.9)$ & $32(29.1)$ \\
\hline $26-30$ & $19(17.3)$ & $13(11.8)$ & $24(21.8)$ \\
\hline$>30$ & $15(13.6)$ & $9(8.2)$ & 220 \\
\hline Total & 110 & 110 & $\mathrm{p}$ value $<0.02$ \\
\hline Mean \pm SD & $24.40 \pm 4.06$ & $23.39 \pm 3.66$ & \\
\hline
\end{tabular}

Table 2: Mode of delivery in study and control groups.

\begin{tabular}{|llll|}
\hline Mode of Delivery & Study $\mathbf{n}(\%)$ & Control $\mathbf{n}(\%)$ & P value \\
\hline LSCS & $43(39.1)$ & $21(19.1)$ & 0.021 \\
\hline Vaginal & $67(60.9)$ & $89(80.9)$ & $\mathbf{1 1 0}(\mathbf{1 0 0})$ \\
\hline Total & $\mathbf{1 1 0}(\mathbf{1 0 0})$ & & \\
\hline
\end{tabular}

This shows that higher age group had more number of cases with unengaged head (Table 1).
The controls had higher no. of vaginal delivery than study group. More no. of LSCS i.e. about $39.1 \%$ in study group 
as compared to $21 \%$ of controls is statistically significant difference ( $\mathrm{p}$ value 0.05 ) (Table 2).

Among indication of LSCS, NPOL was the cause in about $55.81 \%$ of study group and only $28.5 \%$ of controls.
This is statistically significant. Hence, NPOL occurred more frequently in study group (Table 3). Study group had higher no. of complication (35.8\%) when compare to controls $(13.4 \%)$ and this is statistically significant $(\mathrm{p}<0.001)$ (Table 4).

Table 3: Indication of LSCS.

\begin{tabular}{|c|c|c|c|c|c|}
\hline \multirow{2}{*}{ Indication of LSCS } & \multicolumn{2}{|l|}{ Study } & \multicolumn{2}{|l|}{ Control } & \multirow{2}{*}{ P value } \\
\hline & No of patients & Percentage & No of patients & Percentage & \\
\hline Fetal Distress & 9 & $20.93 \%$ & 11 & $52.3 \%$ & \multirow{3}{*}{0.020} \\
\hline NPOL & 24 & $55.81 \%$ & 06 & $28.5 \%$ & \\
\hline DTA & 10 & $23.25 \%$ & 4 & $19.0 \%$ & \\
\hline Total & 43 & $100 \%$ & 21 & $100 \%$ & \\
\hline
\end{tabular}

Table 4: Maternal complications.

\begin{tabular}{|llll|}
\hline Maternal complications & Study $(\mathbf{n}=\mathbf{1 1 0})$ & Controls $(\mathbf{n = 1 1 0})$ & P value \\
\hline \multirow{2}{*}{ Cervical Tear } & 18 & 9 & $<0.001$ \\
\cline { 2 - 4 } PPH & $16.4 \%$ & $8.2 \%$ & $<0.001$ \\
\hline
\end{tabular}

\section{DISCUSSION}

We studied 220 cases of primigravida at term at onset of labour. The study consisted of 220 primigravida of which 110 had unengaged head as study group and 110 engaged head as controls.

\section{Age distribution}

In the present study age difference between study group and controls was statistically significant. About $13.6 \%$ in study group and only $8.2 \%$ in control group had $>30$ years of age. The mean age was $24.40 \pm 4.06$ years for study group and $23.39 \pm 3.66$ years for control comparison with the study. This shows that higher age group had more no. of cases in study group as compared to controls.

\section{Mode of delivery}

In the present study more number of LSCS i.e. about $39.1 \%$ in unengaged group as compared to $19.1 \%$ of engaged head is statistically significant ( $p$ value 0.021 ) The present study on comparing with Saima et al. ${ }^{7}$ and Mahendra G et al, rate of LSCS in unengaged head is comparable and statistically significant. ${ }^{8}$

Table 5: Incidence of LSCS in various studies.

\begin{tabular}{|c|c|c|c|c|}
\hline Station of head & Saima et $\mathbf{a l}^{7}$ & Mahendra et $\mathbf{a l}^{8}$ & Dayal et al9 & Present study \\
\hline Unengaged head & $38 \%$ & $37 \%$ & $21 \%$ & $39.1 \%$ \\
\hline Engaged head & $15 \%$ & $7 \%$ & $8 \%$ & $19.1 \%$ \\
\hline
\end{tabular}

\section{Indication of LSCS}

In present study caesarean was done in $39.1 \%$ study group, with maximum number of caesarean sections performed due to non-progress of labour in $54.28 \%$. Compared with the study conducted by Mahendra $\mathrm{G}$ et al, most common indication for caesarean section was nonprogress of labour in $55.81 \% .^{8}$ In present study caesarean section done in engaged head in $19.1 \%$, maximum no. of caesarean section was performed due to foetal distress.

\section{Maternal outcome}

Study group had higher no. of complication $(35.8 \%)$ when compare to controls (13.4\%) and this is statistically significant $(\mathrm{p}<0.001)$. Incidence of cervical tear and PPH i.e. $16.4 \%$ and $10 \%$ respectively is slightly on higher side 
in study groups as compared to $8.2 \%$ and $3.6 \%$ respectively in controls.

According to Pahwa $\mathrm{S}$ et al, out of 4 cases of cervical tear, 1 case was with FF group while rest 3 cases with -3 station. ${ }^{10}$ Out of 19 cases of PPH, 7 were in FF, 9 in 3 station, 2 cases in - 2 station and 1 case in - 1 station. This is comparable to our study in which higher number of cases of cervical tear and $\mathrm{PPH}$ were found in unengaged head than engaged head.

\section{CONCLUSION}

It is concluded that a nullipara with unengaged foetal head at onset of labour belongs to higher age order and higher incidence of caesarean section. Patients with engaged head had higher no. of vaginal delivery than patients with unengaged head. More no. of LSCS i.e. about $39.1 \%$ in patients with unengaged head as compared to $21 \%$ of patients with engaged head is statistically significant difference ( $p$ value 0.034 ).

Funding: No funding sources

Conflict of interest: None declared

Ethical approval: Not required

\section{REFERENCES}

1. Romero Ian Donald's Practical obstetric problems, seventh edition; 2014:465.

2. Ambwani BM. Primigravida with floating head at term or onset of labour. Int $\mathbf{J}$ Gynaecol Obstet. 2004;3(1):1.
3. Debby A, Rotmenseh S, Girtler O, Sadan O, Golan A, Glezerman M. Clinical significance of floating head in nulliparous women in labour. J Reprod Med. 2003;48:37-40.

4. Yousuf R, Baloch SN. An audit of ceasarean section. Pak J Med Res. 2006;45:28-31.

5. Jafarey SN. Maternal mortality in Pakistan compilation of available data. J Pak Med Assoc. 2002;52:539-54.

6. Macara LM, Murphy KW. The contribution of dystocia to caesarean. Am J Obstet Gynecol. 1994;171(1):71-7.

7. Iqbal S, Sumaira S. Outcome of primigravida with unengaged versus engaged foetal head at term or onset of labour. Biomed. 2009;2:159-62.

8. Prameela MG. Outcome of unengaged head in primigravida at term at onset of labour. Int J Recent Trends Sci Tech, 2014;1(2):345-9.

9. Dayal S, Dayal A. Outcome of Labour in Nullipara at term with unengaged vertex. Int J Med Res Rev. 2014;2(2):130-4.

10. Pahwa S, Kaur A, Nagpal M. Obstetric outcome of floating head in primigravida at term. Int $\mathrm{J}$ Reprod Contracept Obstet Gynecol. 2018 ;7(1):242-24.

Cite this article as: Goyal A, Wadhwani R. Maternal outcome of primigravida patient with term pregnancy with engaged versus unengaged foetal head at onset of labour. Int J Reprod Contracept Obstet Gynecol 2019;8:3037-40. 